\title{
Cellular responses to ionising radiation of AT heterozygotes: differences between missense and truncating mutation carriers
}

\author{
M Fernet', N Moullan', A Lauge ${ }^{2}$, D Stoppa-Lyonnet ${ }^{2}$ and J Hall*,I \\ 'DNA Repair Group, International Agency for Research on Cancer, 150 cours Albert Thomas, 69372 Lyon cedex 08, France; ²Service de Génétique, \\ Institut Curie, 26 rue d'Ulm, 75248 Paris cedex 05, France
}

Ataxia telangiectasia (AT) is a rare autosomal recessive multisystemic disorder with neurological, cutaneous and immunological abnormalities. This disease is associated with an elevated risk of malignancy, primarily leukaemias and lymphomas, and a high radiosensitivity. The gene defective in this syndrome, ATM (AT mutated), encodes a nuclear $350 \mathrm{kDa}$ phosphoprotein containing a carboxy terminus phosphatidylinositol $3^{\prime}$-kinase (PI-3' kinase) catalytic domain shared by members of a superfamily of large eukaryotic proteins involved in intracellular signalling, DNA damage-induced cell cycle checkpoints, DNA repair and recombination (reviewed in Khanna et al, 2001). After exposure of cells to ionising radiation (IR) or radiomimetic drugs, ATM's kinase activity increases several-fold, although the protein level remains unchanged. In the DNA-damage response pathway, ATM acts upstream of p53 to induce cell cycle arrest at the $G_{1} / S$ and $G_{2} / M$ boundaries and a slowing of the $S$ phase (Hoekstra, 1997). At least part of this activation mechanism involves phosphorylation of p53 on serine-15 that may contribute to the increased half-life of p53 by facilitating its dissociation from MDM2, a protein that promotes p53 proteolysis (Nakagawa et al, 1999). Signalling by ATM also involves interactions with and phosphorylation of the mitotic checkpoints Chk1 and Chk2 (Chen et al, 1999; Matsuoka et al, 2000). Cells from AT homozygotes show a reduced induction of p53 levels after exposure to IR compared with normal cells, and an altered cell cycle progression with an accumulation in the $\mathrm{G}_{2}$

*Correspondence: J Hall; E-mail: hall@iarc.fr

Received I5 May 2003; revised 4 November 2003; accepted 10 November 2003 phase of the cell cycle postirradiation and radioresistant DNA synthesis occurring. Loss of ATM function is also associated with increased genomic instability that contributes to the increased incidence of cancers seen in this syndrome (reviewed in Shiloh, 2003).

A wide spectrum of ATM mutations is found in AT patients. Most are compound heterozygous and, in some populations, there is a strong founder effect (Concannon and Gatti, 1997). About 70\% of the ATM mutations identified in AT patients are truncating mutations $\left(A T M^{\text {trunc }}\right)$, with about $30 \%$ being missense mutations and small in-frame deletions/insertions $\left(A T M^{m i s}\right)$ (Gilad et al, 1996; Stankovic et al, 1998). In many such studies, only the protein truncation test has been used to identify mutations, inevitably creating a bias in the mutations reported; thus, the percentage of truncating mutations could be an overestimate. Truncating mutations act effectively as null mutations, as they result in an unstable protein that is present in very small amounts within a cell. In contrast, missense mutations lead to the expression of a more stable albeit mutant form of the ATM protein, as has been described for the few homozygotes carriers of missense mutations that have been studied (Angelè et al (2003) and references therein).

Heterozygous carriers of the ATM gene (AT hets) have been estimated to comprise $0.36-1 \%$ of the general population. These individuals show none of the severe clinical symptoms seen in AT patients, but have a higher risk of developing several forms of cancer, particularly breast cancer (BC) in women and an earlier age at death from ischaemic heart disease than noncarriers ( $\mathrm{Su}$ and Swift, 2000). On the basis of the increased risk of BC and the heterozygote frequency in the general population, it has been estimated that about $5 \%$ of $\mathrm{BC}$ patients could be $A T M$ mutation 
carriers. Since the ATM gene was cloned, many efforts have been made to evaluate the public health implications of this observation by screening cohorts of BC patients for ATM mutations. The first published studies produced conflicting results, and did not reveal the magnitude of involvement of the ATM gene in sporadic $\mathrm{BC}$ that would have been expected from the increased risk found in the AT family studies and the frequency of AT heterozygotes in the population. To resolve this paradox, it has been hypothesised that there are two populations of AT carriers, one group with a truncating allele coupled with a normal allele (AT hets ${ }^{\text {trunc }}$ ) and a second group with a missense mutation coupled with a normal allele (AT hets ${ }^{\mathrm{mis}}$ ), and that the latter group might be more prone to cancer development (McConville et al, 1996; Gatti et al, 1999; Meyn, 1999). Indeed, there is some experimental evidence that carrying an ATM missense mutation could lead to a dominantnegative phenotype in human cell lines (Chenevix-Trench et al, 2002; Scott et al, 2002), with competition between the mutant and the wild-type forms of the ATM protein.

The establishment of ATM heterozygosity is essential for the estimation of cancer risks and genetic counselling. For instance, intermediate sensitivity to IR has been documented in cell lines from AT heterozygotes using the measurement of cell survival or chromosome damage induction as end points (Chen et al, 1978; Rosin and Ochs, 1986; Shiloh et al, 1986; Scott et al, 1996; Tchirkov et al, 1997; Neubauer et al, 2002). However, many such studies have characterised only cell lines carrying truncating mutations, and some variability in the cellular responses has been noted between different cell lines (Nagasawa et al, 1985; Shiloh et al, 1989; Pandita and Hittelman, 1994; Djuzenova et al, 1999). In order to establish which methods, other than mutation screening, might provide reliable end points for determining ATM heterozygosity, we have compared the cellular phenotype before and after exposure to IR of AT heterozygote cell lines with that seen in cell lines carrying a wild type or homozygous mutated ATM gene. To assess whether $A T M^{\text {mis }}$ and $A T M^{\text {trunc }}$ mutations have distinct effects on ATM protein function, this comparison was made using three heterozygote cell lines carrying missense and 11 carrying truncating mutations. The end points examined were the constitutive levels of ATM mRNA and protein expression and the cell cycle delay in $\mathrm{G}_{2}$ phase, the phosphorylation of Chk2 and serine 15 of p53 and the cell survival after exposure to IR.

\section{MATERIALS AND METHODS}

\section{Cell lines}

Lymphoblastoid cell lines (LCLs), established by Epstein-Barr virus infection of ficoll-purified lymphocytes, were used throughout this study. The seven normal LCLs (IARC 2139, 2145, 2093, 1326, 1663, 1104 and 2209) and the six AT LCLs (IARC AT3, AT6, AT8, AT11, AT13 and AT14) were obtained from Dr Gilbert Lenoir (Institute Gustave Roussy, Villejuif, France). All the AT LCLs carried ATM mutations resulting in a truncated ATM protein (Gilad et al, 1996; Hacia et al, 1998; Angèle et al, 2003). It should be noted that the AT lines IARC AT13 and AT14 were established from sibling pairs and carry the same homozygous truncating mutation. The ATM gene status of the normal cell lines has been previously determined using the restriction endonuclease fingerprinting technique, and all lines carried a wild-type ATM gene (unpublished data). The 14 AT heterozygote LCLs used in this study were all established from the parents of AT children. The ATM gene status in these lines was determined using the FAMA technique (Verpy et al, 1994). All carried either a truncating or a missense mutation (Table 1). The cell line 1-21953 was found to be carrying a missense sequence alteration G544C and a truncating mutation trp2368stop. This missense alteration has not been previously described as a polymorphism in the ATM mutation database (http://www.benaroyaresearch.org/bri_investigators/ atm.htm). It has been reported as a rare variant (allele frequency 0.015 ) by Izatt et al (1999), and found in the heterozygous state in four out of 65 individuals of North African origin (Hall, unpublished data), and thus was considered as an ATM polymorphism in this present study.

Table I Characteristics of AT heterozygote cell lines

\begin{tabular}{|c|c|c|c|c|c|c|c|c|c|c|}
\hline \multirow[b]{2}{*}{ Cell line } & \multirow{2}{*}{$\begin{array}{l}\text { Mutation type } \\
\text { Position (amino-acid change) }\end{array}$} & \multirow{2}{*}{$\begin{array}{l}\text { Mutation } \\
\text { localisation }\end{array}$} & \multicolumn{3}{|c|}{ Cell survival } & \multirow{2}{*}{$\begin{array}{l}\text { Cell } \\
\text { cycle } \\
\text { G2/GI }\end{array}$} & \multirow{2}{*}{$\begin{array}{l}\text { ATM } \\
\text { protein } \\
\text { level }\end{array}$} & \multirow{2}{*}{$\begin{array}{l}\text { ATM } \\
\text { mRNA } \\
\text { level }\end{array}$} & \multirow[b]{2}{*}{ p53-ser I 5} & \multirow[b]{2}{*}{ Chk2 } \\
\hline & & & I Gy & $2 \mathbf{G y}$ & $4 \mathrm{~Gy}$ & & & & & \\
\hline $1-17178$ & Truncating - 38I delA (ter aa |280) & Exon 7 & AT & AT & AT & $\mathrm{N}$ & $\ln t$ & AT & $N$ & $N$ \\
\hline $1-19320$ & Truncating - 3403dell $74($ NP-58aa $)$ & Exon 26 & Int & Int & AT & $\mathrm{N}$ & $\operatorname{lnt}$ & Int & $\mathrm{N}$ & $\mathrm{N}$ \\
\hline $1-2 \mid 954$ & Truncating - 3576dell 70 (ter aal 196) & Exon 27 & lnt & $\operatorname{lnt}$ & AT & $\mathrm{N}$ & $N$ & $\operatorname{lnt}$ & $\mathrm{N}$ & $\mathrm{N}$ \\
\hline $1-17179$ & Truncating - 37II del5 (ter aal243) & Exon 27 & $N$ & $N$ & AT & $\mathrm{N}$ & $N$ & AT & $N$ & $\mathrm{~N}$ \\
\hline $1-17814$ & Truncating - 466l insA (ter aal560) & Exon 33 & AT & $\operatorname{lnt}$ & AT & $\mathrm{N}$ & $N$ & $N$ & $N$ & $\mathrm{~N}$ \\
\hline $10-572$ & Truncating - C6004T (gln202stop) & Exon 42 & $N$ & $\operatorname{lnt}$ & AT & $\operatorname{lnt}$ & $\ln t$ & $\ln t$ & lnt & $N$ \\
\hline $1-17180$ & Truncating - C7327T (arg2443stop) & Exon 52 & AT & $\operatorname{lnt}$ & Int & $N$ & $\operatorname{lnt}$ & $\operatorname{lnt}$ & $N$ & $\mathrm{~N}$ \\
\hline $1-17815$ & Truncating - 7789dell 39 (ter aa2599) & Exon 55 & AT & AT & AT & $\mathrm{N}$ & $\operatorname{lnt}$ & Int & lnt & $\mathrm{N}$ \\
\hline $1-21953$ & Truncating - G7913A (trp2638stop) & Exon 55 & AT & AT & AT & $\mathrm{N}$ & $N$ & Int & $N$ & $\mathrm{~N}$ \\
\hline $1-17052$ & Truncating - 8030delA (ter aa268I) & Exon 57 & AT & AT & AT & $\mathrm{N}$ & $N$ & AT & $N$ & $N$ \\
\hline \multirow[t]{2}{*}{$10-573$} & Truncating - C8|40T (gln27|4stop) & Exon 57 & $N$ & N & Int & $\mathrm{N}$ & lnt & AT & $N$ & $\mathrm{~N}$ \\
\hline & All Truncating & & $\operatorname{lnt}$ & $\operatorname{lnt}$ & AT & $N$ & $\ln t$ & $\operatorname{lnt}$ & $N$ & $N$ \\
\hline $1-15308$ & Missense - TG7875GG (asp-ala2652glu-pro) & Exon 55 & AT & AT & AT & $\mathrm{N}$ & $N$ & $N$ & Int & $\mathrm{N}$ \\
\hline $1-17053$ & Missense - T8489G (val2830gly) & Exon 60 & AT & AT & AT & $\mathrm{N}$ & $\operatorname{lnt}$ & $N$ & $\operatorname{lnt}$ & $\mathrm{N}$ \\
\hline \multirow[t]{2}{*}{$1-25065$} & Missense - T8479G (phe2827ile) & Exon 60 & $\operatorname{lnt}$ & AT & AT & $\mathrm{N}$ & $N$ & $\operatorname{lnt}$ & $N$ & $N$ \\
\hline & All Missense & & AT & AT & AT & N & $N$ & $\ln t$ & $N$ & $N$ \\
\hline All & & & $\operatorname{lnt}$ & $\operatorname{lnt}$ & AT & $\mathrm{N}$ & $\operatorname{lnt}$ & $\operatorname{lnt}$ & $\mathrm{N}$ & $N$ \\
\hline
\end{tabular}

$\overline{{ }^{a} N P}$ - native protein lacking 58 amino acids encoded by exon 26. ter - protein termination. ' $N$ ' and 'AT' mean that the results obtained for the AT het line were not statistically significantly different from that obtained for the normal or AT LCLs, respectively. 'Int' means that this result was significantly different from those of both the normal and AT LCLs. 
LCLs were routinely maintained at $37^{\circ} \mathrm{C}$, in a humidified incubator with $5 \% \mathrm{CO}_{2}$, in exponential growth by dilution twice a week to $5 \times 10^{5}$ cells ml $^{-1}$ in RPMI1640 medium (Gibco, Invitrogen Corporation, Cergy-Pontoise, France) supplemented with 10\% heat-inactivated foetal calf serum (Integro b.v, Zaandan, Holland) and penicillin and streptomycin $\left(100 \mu \mathrm{g} \mathrm{ml}^{-1}, \mathrm{Gibco}\right)$.

\section{ATM protein expression}

A whole-cell protein extract was prepared, as previously described, from lymphoblastoid cells plated at $5 \times 10^{5}$ cells, the day before extraction (Jongmans et al, 1998). $50 \mu \mathrm{g}$ of this protein extract was separated on a $6 \%$ biphasic SDS - polyacrylamide gel, transferred overnight at $30 \mathrm{~V}$ onto a PVDF membrane (Roche Diagnostics) using the Bio-Rad Trans-Blot Cell (Bio-Rad, Marnes la Coquette, France) and immunoblotted using an ATM antibody (AHP392, Serotec, 1/1000 dilution) and a ku80 antibody (AHP317, Serotec, 1/ 40000 dilution). After a $2 \mathrm{~h}$ incubation with the primary antibodies, the membranes were probed with peroxidase-conjugated goat anti-rabbit IgG (DAKO, Denmark) and developed using a chemiluminescence procedure (Amersham, Piscataway, NJ, USA). The expression levels of each protein were determined by densitometry, after correction for protein loading using Ku80 as an internal standard (ATM/Ku80 ratio). Measurements were made at least twice using two independently prepared protein extracts.

\section{Analysis of ATM mRNA levels}

RNA isolation and cDNA synthesis Total RNA was isolated from $0.5 \times 10^{7}$ cells plated at $5 \times 10^{5}$ cells $\mathrm{ml}^{-1}$ the day before extraction, using the RNazol extraction method (Invitrogen). Reverse transcription was carried out on $5 \mu \mathrm{g}$ of total RNA in a $20-\mu \mathrm{l}$ reaction volume containing $1 \times$ first-strand buffer, $200 \mathrm{U}$ of Superscript II RNase H-reverse transcriptase, $40 \mathrm{U}$ of RNase inhibitor (Promega, Charbonnieres, France), $10 \mathrm{~mm}$ DTT (Invitrogen), $125 \mathrm{~mm}$ of each dNTP and $0.5 \mu \mathrm{g}$ of oligo(dT) ${ }_{15}$ (Promega) for $1 \mathrm{~h}$ at $42^{\circ} \mathrm{C}$. The resulting cDNA were used for real-time amplification reactions.

Quantitative real-time PCR The mRNA levels of the ATM gene were measured following generation of the corresponding cDNA by real-time PCR based on TaqMan chemistry, and quantitated using an ABI PRISM 7900 HT sequence detector system (Applied Biosystems, Les Ulis, France). The cDNA levels of an internal control gene, the Actin gene, were measured and used to normalise the ATM cDNA levels. Oligonucleotide primers and Taqman probes for ATM were designed from the Genbank databases using Primer Express (Applied Biosystems). The probes for human ATM and Actin used in the PCR reactions were located in two adjacent exons of each gene to avoid amplification of any genomic DNA contaminating the cDNA.

The ATM forward primer was $5^{\prime}$-GAGCAGAGTCTTGCCCTGAGTATT- $3^{\prime}$ and the reverse primer was $5^{\prime}$-TTGCCACAAACCCTCAGACA-3'.

The Actin forward primer was $5^{\prime}$-CTGGCACCCAGCACAATG-3' and the reverse primer was $5^{\prime}$-GCCGATCCACACGGAGTACT- $3^{\prime}$.

The Taqman probe for ATM was $5^{\prime}$-CTGTGCAGCGAACAATCCCAGCCT $-3^{\prime}$ and had a fluorescent reporter dye (FAM) covalently linked to its $5^{\prime}$ end. The Taqman probe for Actin was $5^{\prime}$ TCAAGATCATTGCTCCTCCTGAGCGC- $3^{\prime}$ and had a fluorescent reporter dye (TET) covalently linked to its $5^{\prime}$. The nonfluorescent quencher dye BHQ1 was linked to the $3^{\prime}$ end of each probe. The reaction mixture contained $0.2 \mu \mathrm{l}$ of cDNA template, $50 \mathrm{nM}$ of Actin primers, $2 \mu \mathrm{M}$ of $A T M$ primers, $100 \mathrm{nM}$ of TaqMan ATM probe, $200 \mathrm{~nm}$ of TaqMan Actin probe and $1 \times$ TaqMan universal master mix (Applied Biosystems). Amplification and detection of specific products was carried out in an ABI PRISM $7900 \mathrm{HT}$ sequence detection system (Applied Biosystems) using an amplification protocol consisting of an initial denaturing and enzyme activation at $95^{\circ} \mathrm{C}$ for $10 \mathrm{~min}$, followed by 35 cycles at $94^{\circ} \mathrm{C}$ for $15 \mathrm{~s}$ and $62^{\circ} \mathrm{C}$ for $1 \mathrm{~min}$. For each sample, three independent RNA extractions have been analysed, with each corresponding cDNA analysed six times on the same plate.

The threshold cycle $(\mathrm{Ct})$, defined as the cycle where the amplification of the PCR product enters the exponential phase, was determined for each gene by plotting the fluorescence level $v s$ the cycle number on a logarithmic scale. The relative expression level of the ATM gene in the different cell lines was then estimated using a semiquantitative method, by calculating the DCt value, defined as the difference in the $\mathrm{Ct}$ value for the target (ATM) and the reference gene (Actin). The results are expressed as the ratio $100 / \mathrm{DCt}$ for ease of interpretation.

\section{Cell survival}

The radiation survival of the LCLs was measured by their relative growth at $72 \mathrm{~h}$ postirradiation (Gilad et al, 1996). The cells were seeded at $2 \times 10^{5}$ cells ml $^{-1}$ the day before irradiation and cell survival was assessed 3 days after exposure to 0,1,2 and $4 \mathrm{~Gy}$ from a ${ }^{137} \mathrm{Cs}$ source, at a dose rate of about $5 \mathrm{~Gy} \mathrm{~min}^{-1}$, by counting the number of living cells using trypan blue exclusion. The number of viable cells in the nonirradiated culture $72 \mathrm{~h}$ postirradiation was considered as $100 \%$ cell survival. Experiments were performed at least twice on each cell line with at least one normal and one AT LCL being analysed in parallel.

\section{p53 and Chk2 phosphorylation}

Measurements of p53-ser15 and Chk2 phosphorylation were made in total protein extracts prepared from control or irradiated ( $5 \mathrm{~Gy})$ LCLs $\left(10^{7}\right.$ cells plated at $5 \times 10^{5}$ cells $\mathrm{ml}^{-1}$ the day before $)$. Briefly, cells were collected from untreated or treated cells 2 and $4 \mathrm{~h}$ after treatment, washed twice in PBS and lysed in TGN buffer $(50 \mathrm{~mm}$ Tris- $\mathrm{HCl} \mathrm{pH} 7.5,150 \mathrm{~mm} \mathrm{NaCl}, 1 \%$ Tween $20,0.2 \%$ Nonidet-P40, $0.2 \mathrm{mg} \mathrm{ml}^{-1}$ pefabloc $^{\mathrm{R}}$ (Boehringer, Roche Diagnostics, Grenoble, France), $1 \mathrm{~mm}$ sodium fluoride, $1 \mathrm{~mm}$ sodium orthovanadate, $10 \mu \mathrm{g} \mathrm{ml}^{-1}$ aprotinin, $2 \mu \mathrm{g} \mathrm{ml}^{-1}$ pepstatin A and $5 \mu \mathrm{g} \mathrm{ml}^{-1}$ leupeptin for $30 \mathrm{~min}$ on ice. The supernatant was collected after centrifugation for $15 \mathrm{~min}$ at 15000 r.p.m. $\left(4^{\circ} \mathrm{C}\right)$, and its protein concentration determined using the BIO-RAD protein assay. $50 \mu \mathrm{g}$ of this protein extract was separated on a $10 \%$ biphasic SDSpolyacrylamide gel and transferred overnight onto a PVDF membrane, as described above. The p53-ser 15 phosphorylation was measured using a specific p53-phosphoserine 15 antibody (\#9284, Cell Signaling Technology, 1/1000 dilution), and the Chk2 phosphorylation was detected by the mobility shift of the protein using a specific Chk 2 antibody (477, Abcam, 1/1500 dilution). The expression levels of each protein were determined by densitometry, after correction for protein loading using Ku80 as an internal standard, as described above. Measurements were made at least twice from a minimum of two independently prepared protein extracts.

\section{Cell cycle analysis}

$7.5 \times 10^{6}$ cells (plated at $5 \times 10^{5}$ cells ml $^{-1}$ ) were plated into two flasks and left to grow overnight. One flask was subsequently used as a control and the second treated with $5 \mathrm{~Gy}$ of IR. At 0,24 and $48 \mathrm{~h}$ postirradiation, an aliquot of the control and treated cells were collected, washed in PBS and treated with propidium iodide using the CycleTest ${ }^{\mathrm{TM}}$ Plus Kit (Becton Dickinson, Pont-de-Claix, France), according to the manufacturer's instructions. The DNA content was analysed by flow cytometry (FACSCalibur, Becton Dickinson), using the CellQuest software; 10000 events were analysed for each sample. The percentage of cells in each phase of the cell cycle was determined using the ModFit programme. 
Experiments were performed at least in duplicate on each cell line. The cell cycle defect was investigated by calculation of the ratio ( $\%$ of cells in $\mathrm{G}_{2}$ phase)/(\% of cells in $\mathrm{G}_{1}$ phase), representative of the delay in $\mathrm{G}_{2}$ occurring after exposure to IR (Lavin et al, 1992).

\section{Statistical methods}

The differences in the basal levels of ATM mRNA and ATM protein, cell survival and the induction of the phosphorylation of p53 in response to DNA damage between the LCLs established from the normal donors, the AT homozygote patients and the AT heterozygotes have been tested by the analysis of the variance (ANOVA). For the intergroup comparison, significant heterogeneity in the variance was assessed by the Bartlett test, and, if necessary, transformations of the variables were applied: arc sine of the square root for cell survival after 1 and $2 \mathrm{~Gy}$, and logarithm for ATM protein level and p53 phosphorylation. For some comparisons, it was impossible to stabilise the variance, so a Mann-Whitney $U$-test was used (ATM mRNA level, $\mathrm{G}_{2} / \mathrm{G}_{1}$ ratio and cell survival after $4 \mathrm{~Gy}$ ). All the statistical computations were performed using the STATISTICA software (version 5.97, Statsoft).

\section{RESULTS}

ATM protein and mRNA levels in normal, AT heterozygote and AT cells

The mean values of ATM protein levels for the 14 AT het cell lines, three carrying missense mutations and 11 truncating mutations, in comparison to the three normal cell lines analysed, are presented in Figure 1. The AT cell line (AT11) carrying two heterozygous truncating mutations, with a very low level of ATM protein that is a characteristic of cells from many AT patients, is included as a negative control. On an individual basis, half of the AT het cell lines examined showed a 20-30\% lower expression of ATM protein (Table 1) compared to the normal cell lines. As a group, the AT het LCLs expressed significantly less ATM protein than the normal cell lines $(P=0.002)$, but more than AT11 $(P<0.001)$. There were no statistical differences in the protein levels between the three AT hets ${ }^{\text {mis }}$ LCLs studied, compared to the 11 AT hets ${ }^{\text {trunc }}$

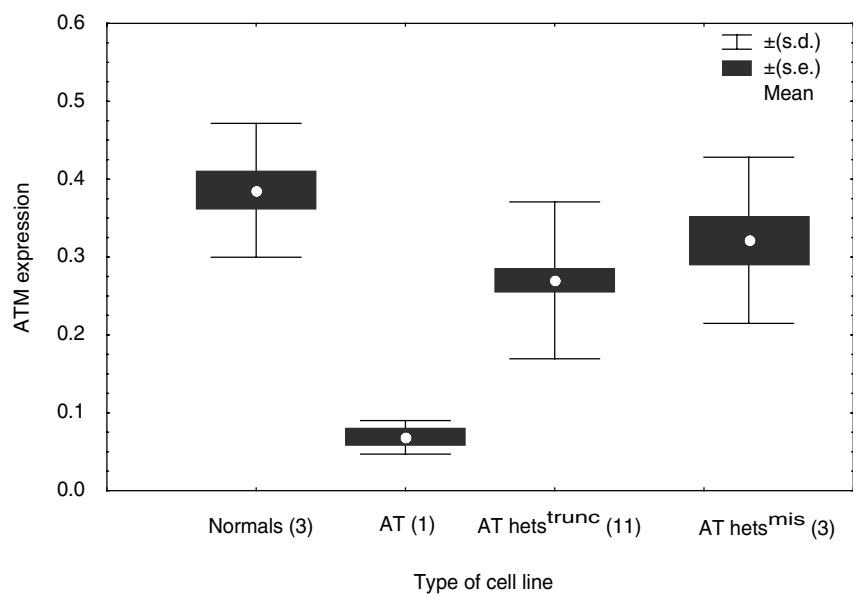

Figure I ATM protein levels in the normal (IARC 2093, 2I45, 2I39), AT (ATII), AT hets ${ }^{\text {trunc }}$ and AT hets ${ }^{\text {mis }}$ LCLs examined. The level of ATM was calculated from the densitometric analysis of Western blot films, after correction for protein loading using Ku80 as a marker. The average intensity \pm s.d. was determined for each group of cell types, with at least two measurements made for each line ( $n=$ number of lines in each group).
LCLs $(P=0.110)$ studied. However, the AT hets ${ }^{\text {trunc }}$ as a group had a statistically lower ATM protein level than the normal cell lines $(P<0.001)$, while the group of AT hets ${ }^{\text {mis }}$ were indistinguishable from the normal LCLs in terms of ATM protein expression $(P=0.102)$.

The mean values of a ratio proportional to the DCt values, representative of the ATM mRNA level, for the six normal, three $\mathrm{AT}$ and all the AT het cell lines are presented in Figure 2. As a group, the AT het cell lines exhibited an intermediate mRNA level lower than that of the normal $(P<0.001)$ and higher than that seen in the AT cell lines $(P<0.001)$, with some variation between the different lines being seen. The AT hets ${ }^{\mathrm{mis}}$ as a group had lower ATM mRNA levels than the normal cell lines $(P=0.002)$, and higher levels than the AT $(P<0.001)$ and AT hets ${ }^{\text {trunc }}(P=0.047)$ cell lines. The mRNA levels in the AT hets ${ }^{\text {trunc }}$ cell lines were also intermediate between the normal $(P<0.001)$ and the AT lines $(P<0.001)$.

\section{Cell survival}

The relative cell survival of the cell lines studied after exposure to 1,2 and $4 \mathrm{~Gy}$ is shown in Figure 3. Statistical analysis of the results was done for each dose separately. The cell survival of the six normal and the six AT cell lines was of the same order, as previously found, under identical experimental conditions (Angèle et al, 2003). Considerable variation was seen between the different AT het cell lines but, as a group, they had a cell survival level which was intermediate and distinguishable between that seen in the normal $(P<0.001)$ and AT $(P<0.001)$ LCLs after exposure to 1 and 2 Gy. It was, however, indistinguishable from that of the AT LCLs after exposure to $4 \mathrm{~Gy}(P=0.604)$.

Differences were noted in the cell survival profile between the two groups of AT het LCLs studied. The group carrying a missense mutation had a lower average cell survival, which was distinguishable from that of the LCLs carrying truncating mutations after exposure to $2 \mathrm{~Gy}(P=0.005)$, but not after exposure to $1 \mathrm{~Gy}$ $(P=0.271)$. The survival of the AT hets ${ }^{\mathrm{mis}}$ was indistinguishable from that of the AT LCLS after exposure to 1 and 2 Gy $(P=0.072$ and 0.803 , respectively), while the AT hets ${ }^{\text {trunc }}$ group showed a higher survival at both doses $(P<0.001$ for 1 and $2 \mathrm{~Gy})$. After exposure to $4 \mathrm{~Gy}$, the two groups of AT hets were as radiosensitive

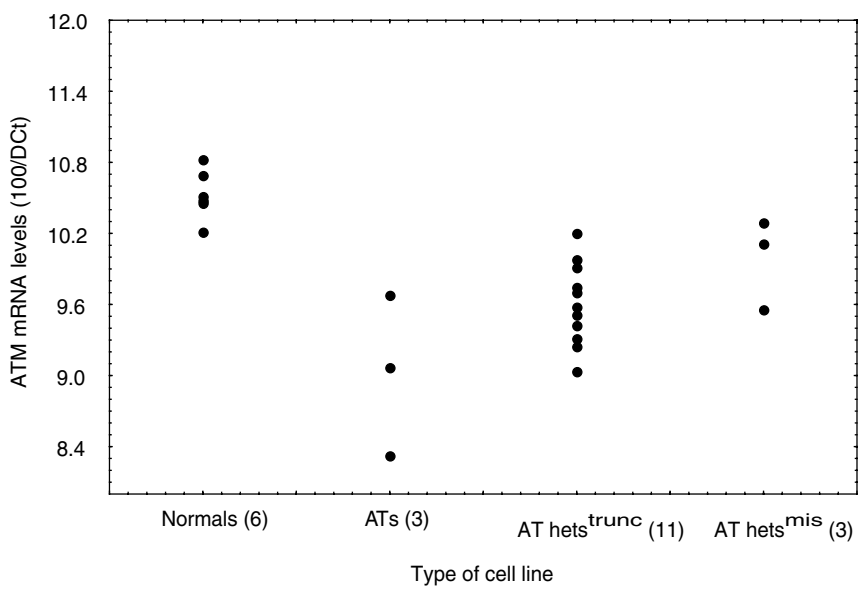

Figure 2 ATM-mRNA level in the six normal, three AT (AT6, ATI I, AT 14), II AT hets ${ }^{\text {trunc }}$ and three AT hets ${ }^{\text {mis }}$ LCLs. The mRNA level, expressed as the ratio 100/DCT, was obtained by TaqMan analysis and correction for RNA content using $\beta$-actin. Data points represent the mean value from at least three experiments for each of the cell lines studied ( $n=$ number of lines in each group), except for AT6 and AT I4, which were assayed twice. 
as the group of AT LCLs $\left(P=0.509\right.$ and 0.755 for AT hets ${ }^{\text {trunc }}$ and AT hets ${ }^{\text {mis }}$, respectively).

\section{Phosphorylation of Chk2 and p53-serine 15}

The phosphorylation of the two ATM-target proteins Chk2 and p53-ser 15 was studied 2 and $4 \mathrm{~h}$ after a 5 Gy irradiation by Western blot analysis (Figure 4). The AT het cell lines were compared with two normal and an AT LCLs, representative of each cell type. As expected, the AT11 LCL exhibited a reduced phosphorylation of p53-ser15 and no shift in the position of Chk2, 2 or $4 \mathrm{~h}$ after exposure to IR, while the normal cell lines showed a maximum p53-ser 15 phosphorylation $2 \mathrm{~h}$ after treatment and a clear shift in the mobility of Chk2. The average levels of the p53-ser15 induction for the four cell types are shown in Figure 5. No differences were noted between the group of AT hets ${ }^{\text {mis }}$ or AT hets ${ }^{\text {trunc }}$ and the normal LCLs ( $P=0.355$ and 0.279 , respectively). However, on an individual cell line basis of the 14 AT hets LCLs studied, a delayed and reduced p53-ser15 phosphorylation was noted in four lines (10-572, 1-17815, 1-15308 and 1-17053). All the AT het cell lines showed a Chk2 bandshift after exposure to IR, as seen in the normal cell lines.

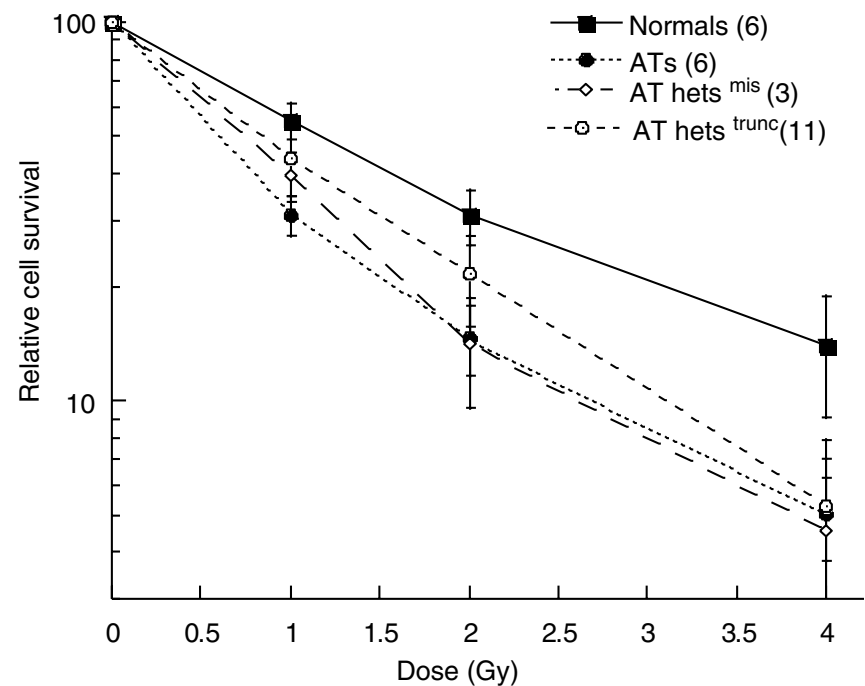

Figure 3 Radiation cell survival curves. The viable cells were counted by trypan blue exclusion 3 days after exposure to gamma radiation. Mean values \pm s.d. for each group of cell lines were established based on the results from at least two independent experiments on each line.

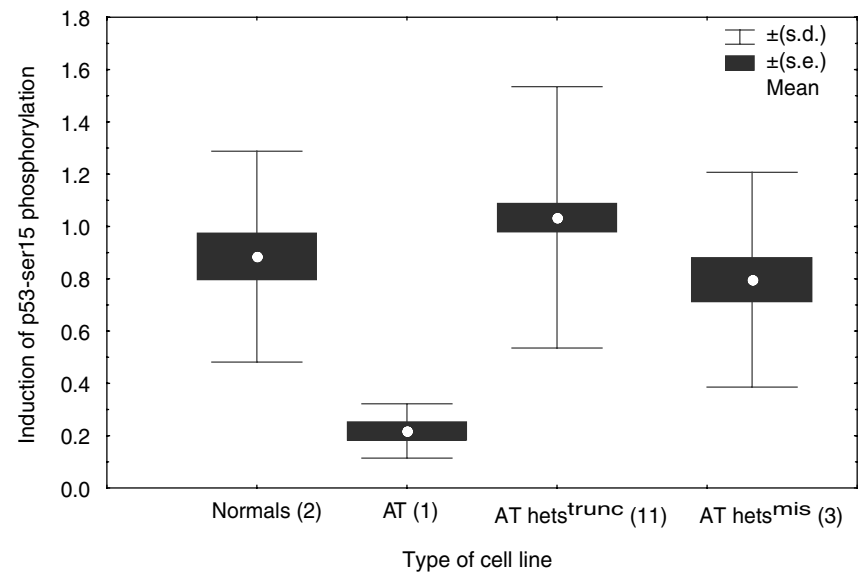

Figure 5 Quantification of the p53-ser 15 phosphorylation, presented as the p53-ser /5/ku80 ratio to correct for variation in protein loading, 2 and $4 \mathrm{~h}$ after exposure to $5 \mathrm{~Gy} I \mathrm{R}$. The average ratio \pm s.d. was calculated for each group of cell lines, based on at least two independent experiments for each line ( $n=$ number of lines).
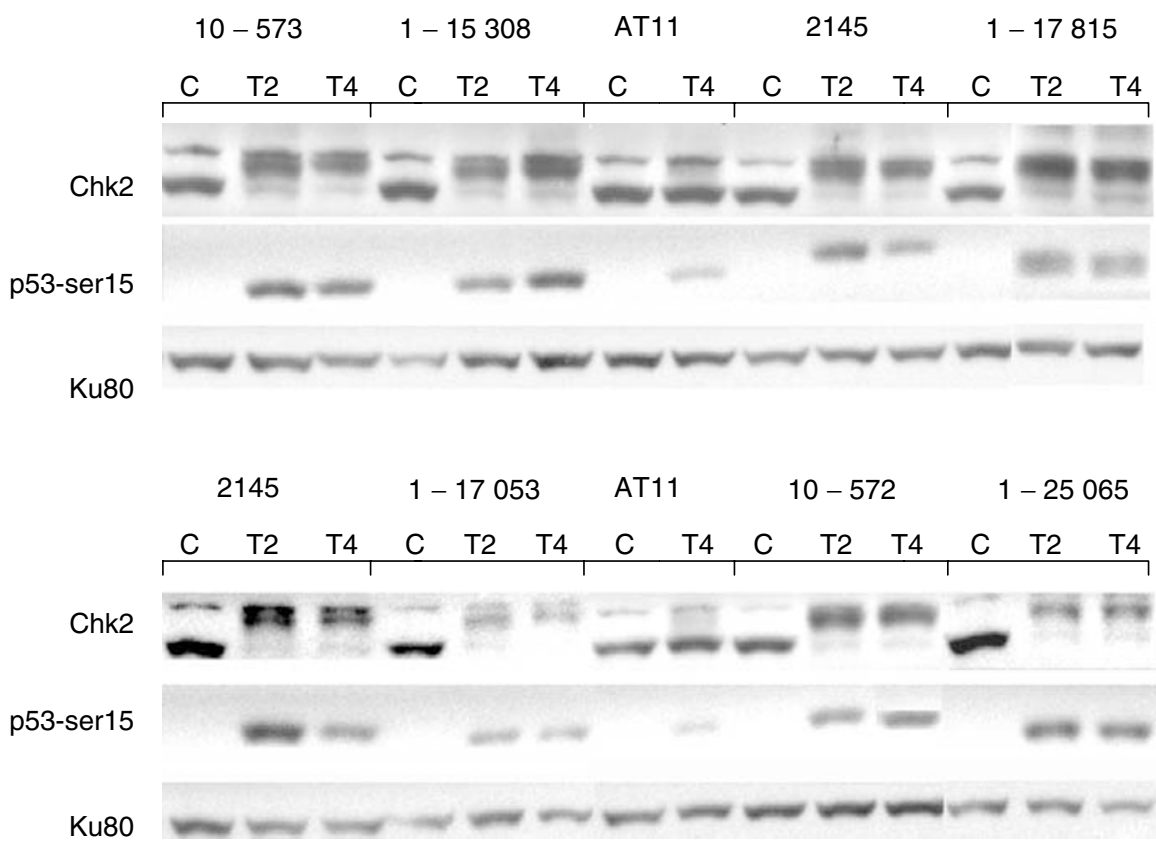

Figure 4 Radiation-induced Chk2 and p53-ser 15 phosphorylation. Protein extracts were prepared from the normal (IARC 2I45), AT (ATI I) and AT heterozygote $(10-573,1-15308,|-17815|-17053,,10-572$ and I -25065$)$ LCLs 2 and $4 \mathrm{~h}$ after exposure to 5 Gy, and from untreated cells. Ku80 immunodetection was performed on each gel to correct for variations in protein loading. Phosphorylation of Chk2 was assessed by the mobility shift of the protein band, while the intensity of the p53-ser 15 bands was analysed by densitometry. 


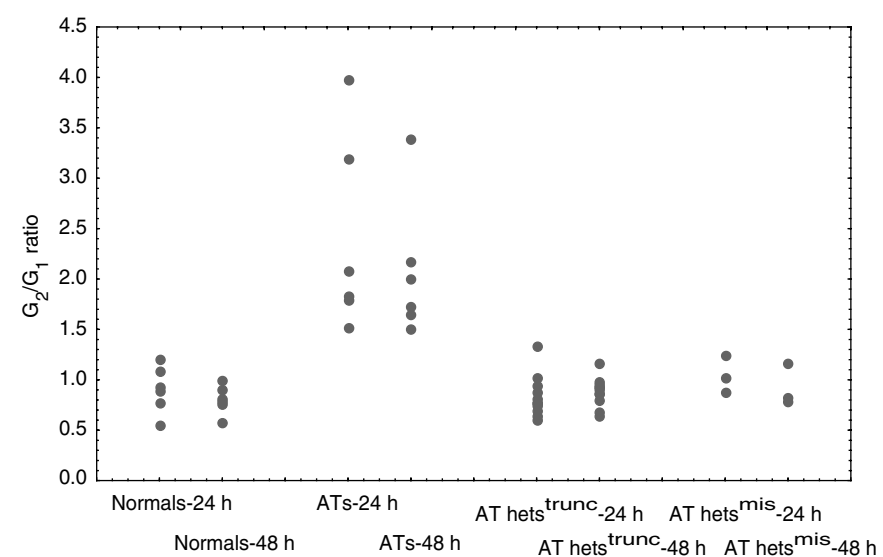

Type of cell line-time after irradiation

Figure 6 Cell cycle delay in $\mathrm{G}_{2}$ phase. This delay was estimated in six normal, six AT and the 14 AT het cell lines, by calculation of the $G_{2} / G_{1}$ ratio, 24 and $48 \mathrm{~h}$ after exposure to $5 \mathrm{~Gy}$. Data points represent the average value for each cell line, based on at least two independent experiments.

\section{Cell cycle progression}

The radiation-induced arrest in the $\mathrm{G}_{2}$ phase of the cell cycle was assessed by calculating the ratio between the percentage of cells in $\mathrm{G}_{2}$ and the percentage of cells in $\mathrm{G}_{1}, 24$ and $48 \mathrm{~h}$ after irradiation (Figure 6). All the statistical analyses were made by taking into account the results at 24 and $48 \mathrm{~h}$ after irradiation. As previously noted, the six AT cell lines showed a greater cell cycle delay in $G_{2}$, reflected in a higher $G_{2} / G_{1}$ ratio, compared to the six normal cell lines $(P<0.001)$ (Angèle et al, 2003). As a group, the 14 AT het cell lines presented $a G_{2} / G_{1}$ ratio similar to that of the normal cell lines $(P=0.382)$, with no differences being noted depending on the type of mutation being carried $\left(P=0.894\right.$ and 0.494 for AT hets ${ }^{\text {trunc }}$ and AT hets ${ }^{\text {mis }}$, respectively). We, however, noted that two AT het LCLs, both carrying a truncating ATM mutation, showed a higher $\mathrm{G}_{2} / \mathrm{G}_{1}$ ratio than the normal LCLs (AT het cell line 10-572, $P=0.025$ and $1-17815, P=0.056)$.

\section{DISCUSSION}

It has been postulated and supported by limited experimental evidence that the presence of $A T M$ missense mutations, in contrast to ATM truncating mutations, may result in a different cellular phenotype after exposure to IR and alter the risk of developing cancers in heterozygote carriers (Stankovic et al, 1998; Gatti et al, 1999; Chenevix-Trench et al, 2002; Scott et al, 2002). We have investigated the constitutive levels of expression of the ATM gene and the in vitro cellular phenotype after exposure to IR in 14 heterozygote cell lines carrying different mutations located throughout the ATM gene, to assess whether mutation-type specific differences could be detected and whether such end points could provide a reliable assay for the identification of ATM carriers. A wide range of responses was noted, extending from that seen in normal cell lines to the extreme reactions seen in homozygote carriers of ATM mutations, with the profile of responses of each line varying in its severity depending on the end point being measured and the treatment dose (Table 1).

As a group, the AT heterozygotes had a reduced level of ATM mRNA expression, which was reflected in a lower average constitutive level of protein expression, compared to the normal LCLs studied. The assessment of the gene expression phenotype has been proposed as a possible means of identifying ATM heterozygotes (Watts et al, 2002), and these results would lend support to this proposal. However, it should be noted that some variation between the different LCLs was noted and no direct relationship between the ATM protein and mRNA levels was seen in all cell lines (Jongmans et al, 1997; Becker-Catania et al, 2000; Sun et al, 2002). In this study, the three AT heterozygote cell lines carrying a missense mutation had higher levels of mRNA levels, as measured by a semiquantitative PCR-based technique compared to the lines carrying truncating mutations, reflecting the observations in ATM homozygote lines. However, differences in ATM protein levels between the two groups of AT hets was not so clearcut, as has been previously reported (Shigeta et al, 1999; Becker-Catania et al, 2000; Delia et al, 2000). It should be noted that, under the experimental conditions used, no truncated forms of the ATM protein were detected in any of the heterozygote lines examined. It cannot be excluded that differences in expression may also exist between the two ATM alleles, as has been found to be the case in $\mathrm{XP}-\mathrm{C}$ heterozygotes where the expression of the normal allele predominated (Chavanne et al, 2000).

Enhanced cell killing in response to treatment with IR is one characteristic of all ATM homozygote cells, but the level of this radiosensitivity in ATM heterozygote cells appears more variable. Many authors have reported a level of cell survival intermediate between that seen in normal and ATM homozygote cells, but, in other studies, some overlap or no statistically significant differences between normal and AT het cell types have been detected (Chen et al, 1978; Kinsella et al, 1982; Nagasawa et al, 1985; Weeks et al, 1991; West et al, 1995; Shigeta et al, 1999; Sun et al, 2002). Many of these studies have used a fibroblast-cloning assay, which requires the trypsinising and replating of treated cells, which may lead to additional cell death, particularly in radiationsensitive cell types. Using a cell proliferation assay, which avoids the manipulation of the treated cells, our results indicated a greater radiosensitivity for the AT heterozygote cells as a group, compared with the normal cells. Some overlap between the results obtained from the AT heterozygote and homozygote cells lines was noted, in particular after exposure to $4 \mathrm{~Gy}$, suggesting that such high doses are not the ideal experimental conditions to distinguish these two cell types. When the distinction between the carriers of missense or truncating mutations was made, we noted that the cell lines carrying missense mutations were more radiosensitive than those carrying truncating mutations after treatment. This observation was based on the overlap of their survival with the AT cell lines at lower doses, which was not seen for the AT het ${ }^{\text {trunc }}$ lines, and the fact that the two groups could be distinguished after exposure to $2 \mathrm{~Gy}$. These findings suggest that the ATM protein containing a missense mutation could act in a dominant-negative manner influencing cell survival.

To evaluate the kinase activity of the ATM protein in the heterozygote cells, the in vivo phosphorylation of the p53-ser15 and Chk2 was assessed after exposure to IR. The AT cell line studied exhibited an approximately five-fold reduced p53-ser15 phosphorylation compared to the two normal cell lines under the experimental conditions used. This p53-ser15 phosphorylation is probably due to the kinase activity of ATR (ATM-related), which is also able to carry out this specific p53 phosphorylation (Matsuoka et al, 2000). However, no Chk2 phoshorylation, as assessed by the alteration of its mobility on the SDS-PAGE gels, was noted in this homozygote line. In contrast, under these same experimental conditions, Chk2 phosphorylation was detected in all the 14 AT heterozygote cell lines, and 10 of the 14 cell lines showed a normal level of p53-ser15 phosphorylation. A possible explanation of this result is that a second kinase activity capable of carrying out these reactions is present in these heterozygote lines at a higher level than seen in normal cell lines, such as increased levels of ATR. It should be noted that these two end points were assessed on the same Western blots, so that these apparently substrate-specific differences could not be explained by variability between protein extracts, but reflect the in vivo pattern of phosphorylation that had 
occurred following exposure to IR. No mutation-type (truncating $v s$ missense) specific differences in the capacity to phosphorylate these ATM-target proteins were noted. Some variation between ATM kinase activity has been reported in the limited number of heterozygote lines previously studied (Delia et al, 2000; Scott et al, 2002), suggesting that these end points are not suitable for evaluating the presence of ATM heterozygosity with certitude.

Alterations in the activation of p53, Chk2 and other proteins lead to disturbances in cell cycle progression after irradiation. Under such conditions, most AT cell lines fail to delay at the $G_{1} / S$ and $\mathrm{G}_{2} / \mathrm{M}$ checkpoints, progressing through the cell cycle to accumulate and die in $G_{2} / M$. Thus, the $G_{2} / G_{1}$ ratio can be used to estimate the accumulation of cells in $G_{2} / M$ after exposure to IR. We found that the AT het cell lines as a group exhibited a delay in $\mathrm{G}_{2}$ similar to that seen in the normal cell lines after such treatment. An intermediate $G_{2}$ delay has been reported previously in some AT het cell lines between that observed in normal and AT cell lines, but overlaps in the response between these three cell types have also been reported (Lavin et al, 1992; Chen et al, 1994; Naeim et al, 1994). One explanation for these differences in the cell cycle profile could be the radiation treatment dose used. In this present study, the cell cycle progression was examined after an exposure to $5 \mathrm{~Gy}$, while other studies have used lower treatment doses ( 2 or $3 \mathrm{~Gy}$ ). It can be reasoned that, even if the pathways controlling the cell cycle progression are not fully operational in AT heterozygote cells, after exposure to higher doses of IR with greater levels of DNA damage being formed, the activation of cell cycle regulation could occur, perhaps through the intervention of other DNA damage-activated kinases, leading to an apparently normal response. The lack of a defect in cell cycle progression in the majority of the AT het LCLs examined after exposure to IR is consistent with the normal activation of p53 and Chk2 observed, two proteins strongly involved in cell cycle checkpoint control. The one AT het line which had a statistically lower $\mathrm{G}_{2} / \mathrm{G}_{1}$ ratio also showed a lower $\mathrm{p} 53$ ser15 phosphorylation after treatment with IR, but a normal Chk2 response underlining the complex interplay of the proteins controlling the cell cycle response to DNA damage. It would appear in spite of a reduced ATM protein level in some ATM carriers that this endogenous protein is sufficient to ensure the functionality of the signalling pathways leading to cell cycle control after exposure to IR, but not to ensure normal levels of cell survival.

The variation between the different AT heterozygote lines studied, especially in terms of ATM mRNA and protein levels and cell survival, is large with some cell lines being indistinguishable from normal cell lines, while others have a cellular phenotype similar to that seen in AT homozygote lines. One explanation for this interindividual variability might be the location of the different ATM mutations within the gene, which may affect ATM protein expression and/or its activity. Morgan et al (1997) demonstrated that the expression of an ATM fragment encoding the leucine zipper domain can act in a dominant-negative manner influencing cell survival, but not p53 induction nor cell cycle checkpoints, while expression of the PI-3 kinase domain is sufficient to ensure ATM kinase activity (Morgan et al, 1997). The mutations carried by the AT heterozygote cell lines included in this present study were located throughout the ATM gene, and all the truncating mutations were located upstream of the conserved
PI-3 kinase domain (codon 60/61). Thus, if a stable truncated protein was expressed, it would contain the leucine zipper domain and could potentially act in a dominant-negative manner, influencing cell survival, as has been demonstrated by Morgan et al (1997). However, its presence would not be expected to impact on the kinase activity, which would originate solely from the protein expressed from the wild-type allele. It is formally possible that alternative start codons in the ATM coding region may exist downstream of the premature termination codons carried in the ATM heterozygotes. Translation initiating at such codons might produce an ATM fragment corresponding to the PI3 kinase domain that could retain kinase activity, as has been shown by Morgan et al (1997). Such an alternative mode of translation has been found in Nijmegen breakage syndrome patients carrying the common founder mutation 657del5 allele, a truncating mutation that causes premature termination at codon 219. In these individuals, an NBS protein lacking the native $\mathrm{N}$ terminus is produced by internal translation initiation within the NBS1 mRNA using an open-reading frame generated by the 657del5 frameshift (Maser et al, 2001).

This study, characterising several aspects of the DNA damage response in 14 AT heterozygote cell lines, highlights their diversity and the difficulties associated with finding a reliable test for the detection of ATM carriers in the general population. Based on the results obtained from the experimental approaches used here, none of the end points alone would allow the assessment of ATM heterozygosity with a $100 \%$ accuracy. As a group, the cell lines with such a genetic profile have reduced ATM mRNA and protein levels, and a lower cell survival following exposure to IR, but on an individual basis some considerable variation is seen, with some AT heterozygote lines resembling lines carrying a wild-type ATM gene. The presence of a missense mutation compared to a truncating mutation is associated with a higher level of ATM mRNA expression, but a lower cell survival, after exposure to IR. The determination of the gene expression profile in AT heterozygotes, in particular genes implicated in cell survival, where the clearest differences were observed experimentally between the carriers and noncarriers of an altered ATM gene, is a promising avenue to be pursued. Watts et al (2002) have also recently reported that LCLs from AT heterozygotes have a specific expression phenotype based on baseline and induced changes in response to IR. One important practical consideration of any approach to identify ATM carriers is the need to extend the results to peripheral blood lymphocytes, which will eliminate the requirement of establishing cell lines and enable its use in a clinical setting.

\section{ACKNOWLEDGEMENTS}

We thank Dr G Lenoir for access to cell lines, Drs S Angèle and S Gutiérrez for helpful discussions and Dr D. Cox for technical advice in setting up the quantitative real-time PCR. The financial support of the French Minister of Education, Research and Technology through its special action in Radiobiology is gratefully acknowledged, and that of La Ligue Contre le Cancer to Dr Marie Fernet. This work was carried out during the tenure of a Special Training Award from the International Agency for Research on Cancer to Norman Moullan.

\section{REFERENCES}

Angèle S, Lauge A, Fernet M, Moullan N, Beauvais P, Couturier J, StoppaLyonnet D, Hall J (2003) Phenotypic cellular characterization of an ataxia telangiectasia patient carrying a causal homozygous missense mutation. Hum Mutat 21: $169-170$
Becker-Catania SG, Chen G, Hwang MJ, Wang Z, Sun X, Sanal O, Bernatowska-Matuszkiewicz E, Chessa L, Lee EY, Gatti RA (2000) Ataxiatelangiectasia: phenotype/genotype studies of ATM protein expression, mutations, and radiosensitivity. Mol Genet Metab 70: 122-133 
Chavanne F, Broughton BC, Pietra D, Nardo T, Browitt A, Lehmann AR, Stefanini M (2000) Mutations in the XPC gene in families with xeroderma pigmentosum and consequences at the cell, protein, and transcript levels. Cancer Res 60: 1974-1982

Chen P, Farrell A, Hobson K, Girjes A, Lavin M (1994) Comparative study of radiation-induced G2 phase delay and chromatid damage in families with ataxia-telangiectasia. Cancer Genet Cytogenet 76: 43-46

Chen P, Gatei M, O'Connell MJ, Khanna KK, Bugg SJ, Hogg A, Scott SP, Hobson K, Lavin MF (1999) Chk1 complements the G2/M checkpoint defect and radiosensitivity of ataxia-telangiectasia cells. Oncogene 18: 249-256

Chen PC, Lavin MF, Kidson C, Moss D (1978) Identification of ataxia telangiectasia heterozygotes, a cancer prone population. Nature 274: $484-486$

Chenevix-Trench G, Spurdle AB, Gatei M, Kelly H, Marsh A, Chen X, Donn $K$, Cummings M, Nyholt D, Jenkins MA, Scott C, Pupo GM, Dork T, Bendix R, Kirk J, Tucker K, McCredie MR, Hopper JL, Sambrook J, Mann GJ, Khanna KK (2002) Dominant negative ATM mutations in breast cancer families. J Natl Cancer Inst 94: 205-215

Concannon P, Gatti RA (1997) Diversity of ATM gene mutations detected in patients with ataxia-telangiectasia. Hum Mutat 10: 100-107

Delia D, Mizutani S, Panigone S, Tagliabue E, Fontanella E, Asada M, Yamada T, Taya Y, Prudente S, Saviozzi S, Frati L, Pierotti MA, Chessa L (2000) ATM protein and p53-serine 15 phosphorylation in ataxiatelangiectasia (AT) patients and at heterozygotes. Br J Cancer 82: 1938 1945

Djuzenova CS, Schindler D, Stopper H, Hoehn H, Flentje M, Oppitz U (1999) Identification of ataxia telangiectasia heterozygotes, a cancerprone population, using the single-cell gel electrophoresis (Comet) assay. Lab Invest 79: $699-705$

Gatti RA, Tward A, Concannon P (1999) Cancer risk in ATM heterozygotes: a model of phenotypic and mechanistic differences between missense and truncating mutations. Mol Genet Metab 68: 419-423

Gilad S, Khosravi R, Shkedy D, Uziel T, Ziv Y, Savitsky K, Rotman G, Smith S, Chessa L, Jorgensen TJ, Harnik R, Frydman M, Sanal O, Portnoi S, Goldwicz Z, Jaspers NG, Gatti RA, Lenoir G, Lavin MF, Tatsumi K, Wegner RD, Shiloh Y, Bar-Shira A (1996) Predominance of null mutations in ataxia-telangiectasia. Hum Mol Genet 5: 433-439

Hacia JG, Sun B, Hunt N, Edgemon K, Mosbrook D, Robbins C, Fodor SP, Tagle DA, Collins FS (1998) Strategies for mutational analysis of the large multiexon ATM gene using high-density oligonucleotide arrays. Genome Res 8: $1245-1258$

Hoekstra MF (1997) Responses to DNA damage and regulation of cell cycle checkpoints by the ATM protein kinase family. Curr Opin Genet Dev 7: $170-175$

Izatt L, Greenman J, Hodgson S, Ellis D, Watts S, Scott G, Jacobs C, Liebmann R, Zvelebil MJ, Mathew C, Solomon E (1999) Identification of germline missense mutations and rare allelic variants in the ATM gene in early-onset breast cancer. Genes Chromosomes Cancer 26: $286-294$

Jongmans W, Vuillaume M, Chrzanowska K, Smeets D, Sperling K, Hall J (1997) Nijmegen breakage syndrome cells fail to induce the p53mediated DNA damage response following exposure to ionizing radiation. Mol Cell Biol 17: 5016-5022

Jongmans W, Vuillaume M, Kleijer WJ, Lakin ND, Hall J (1998) The p53mediated DNA damage response to ionizing radiation in fibroblasts from ataxia-without-telangiectasia patients. Int J Radiat Biol 74: 287-295

Khanna KK, Lavin MF, Jackson SP, Mulhern TD (2001) ATM, a central controller of cellular responses to DNA damage. Cell Death Differ 8: $1052-1065$

Kinsella TJ, Mitchell JB, McPherson S, Russo A, Tietze F (1982) In vitro Xray sensitivity in ataxia telangiectasis homozygote and heterozygote skin fibroblasts under oxic and hypoxic conditions. Cancer Res 42: 3950 - 3956

Lavin MF, Le Poidevin P, Bates P (1992) Enhanced levels of radiationinduced G2 phase delay in ataxia telangiectasia heterozygotes. Cancer Genet Cytogenet 60: 183-187

Maser RS, Zinkel R, Petrini JH (2001) An alternative mode of translation permits production of a variant NBS1 protein from the common Nijmegen breakage syndrome allele. Nat Genet 27: 417-421

Matsuoka S, Rotman G, Ogawa A, Shiloh Y, Tamai K, Elledge SJ (2000) Ataxia telangiectasia-mutated phosphorylates $\mathrm{Chk} 2$ in vivo and in vitro. Proc Natl Acad Sci USA 97: 10389-10394

McConville CM, Stankovic T, Byrd PJ, McGuire GM, Yao QY, Lennox GG, Taylor MR (1996) Mutations associated with variant phenotypes in ataxia-telangiectasia. Am J Hum Genet 59: 320-330
Meyn MS (1999) Ataxia-telangiectasia, cancer and the pathobiology of the ATM gene. Clin Genet 55: 289-304

Morgan SE, Lovly C, Pandita TK, Shiloh Y, Kastan MB (1997) Fragments of ATM which have dominant-negative or complementing activity. Mol Cell Biol 17: 2020-2029

Naeim A, Repinski C, Huo Y, Hong JH, Chessa L, Naeim F, Gatti RA (1994) Ataxia-telangiectasia: flow cytometric cell-cycle analysis of lymphoblastoid cell lines in G2/M before and after gamma-irradiation. Mod Pathol 7: $587-592$

Nagasawa H, Latt SA, Lalande ME, Little JB (1985) Effects of X-irradiation on cell-cycle progression, induction of chromosomal aberrations and cell killing in ataxia telangiectasia (AT) fibroblasts. Mutat Res 148: $71-82$

Nakagawa K, Taya Y, Tamai K, Yamaizumi M (1999) Requirement of ATM in phosphorylation of the human $\mathrm{p} 53$ protein at serine 15 following DNA double-strand breaks. Mol Cell Biol 19: 2828-2834

Neubauer S, Arutyunyan R, Stumm M, Dork T, Bendix R, Bremer M, Varon R, Sauer R, Gebhart E (2002) Radiosensitivity of ataxia telangiectasia and Nijmegen breakage syndrome homozygotes and heterozygotes as determined by three-color FISH chromosome painting. Radiat Res 157: $312-321$

Pandita TK, Hittelman WN (1994) Increased initial levels of chromosome damage and heterogeneous chromosome repair in ataxia telangiectasia heterozygote cells. Mutat Res 310: 1-13

Rosin MP, Ochs HD (1986) In vivo chromosomal instability in ataxiatelangiectasia homozygotes and heterozygotes. Hum Genet 74: 335-340

Scott D, Hu Q, Roberts SA (1996) Dose-rate sparing for micronucleus induction in lymphocytes of controls and ataxia-telangiectasia heterozygotes exposed to 60Co gamma-irradiation in vitro. Int J Radiat Biol 70: $521-527$

Scott SP, Bendix R, Chen P, Clark R, Dork T, Lavin MF (2002) Missense mutations but not allelic variants alter the function of ATM by dominant interference in patients with breast cancer. Proc Natl Acad Sci USA 99: $925-930$

Shigeta T, Takagi M, Delia D, Chessa L, Iwata S, Kanke Y, Asada M, Eguchi M, Mizutani S (1999) Defective control of apoptosis and mitotic spindle checkpoint in heterozygous carriers of ATM mutations. Cancer Res 59: $2602-2607$

Shiloh Y (2003) ATM and related protein kinases: safeguarding genome integrity. Nat Rev Cancer 3: 155-168

Shiloh Y, Parshad R, Frydman M, Sanford KK, Portnoi S, Ziv Y, Jones GM (1989) G2 chromosomal radiosensitivity in families with ataxia-telangiectasia. Hum Genet 84: 15-18

Shiloh Y, Parshad R, Sanford KK, Jones GM (1986) Carrier detection in ataxia-telangiectasia. Lancet 1: 689-690

Stankovic T, Kidd AM, Sutcliffe A, McGuire GM, Robinson P, Weber P, Bedenham T, Bradwell AR, Easton DF, Lennox GG, Haites N, Byrd PJ, Taylor AM (1998) ATM mutations and phenotypes in ataxia-telangiectasia families in the British Isles: expression of mutant ATM and the risk of leukemia, lymphoma, and breast cancer. Am J Hum Genet 62: 334-345

Su Y, Swift M (2000) Mortality rates among carriers of ataxia-telangiectasia mutant alleles. Ann Intern Med 133: 770-778

Sun X, Becker-Catania SG, Chun HH, Hwang MJ, Huo Y, Wang Z, Mitui M, Sanal O, Chessa L, Crandall B, Gatti RA (2002) Early diagnosis of ataxia-telangiectasia using radiosensitivity testing. $J$ Pediatr 140: $724-731$

Tchirkov A, Bay JO, Pernin D, Bignon YJ, Rio P, Grancho M, Kwiatkowski F, Giollant M, Malet P, Verrelle P (1997) Detection of heterozygous carriers of the ataxia-telangiectasia (ATM) gene by G2 phase chromosomal radiosensitivity of peripheral blood lymphocytes. Hum Genet 101: $312-316$

Verpy E, Biasotto M, Meo T, Tosi M (1994) Efficient detection of point mutations on color-coded strands of target DNA. Proc Natl Acad Sci USA 91: $1873-1877$

Watts JA, Morley M, Burdick JT, Fiori JL, Ewens WJ, Spielman RS, Cheung VG (2002) Gene expression phenotype in heterozygous carriers of ataxiatelangiectasia. Am J Hum Genet 71: $791-800$

Weeks DE, Paterson MC, Lange K, Andrais B, Davis RC, Yoder F, Gatti RA (1991) Assessment of chronic gamma radiosensitivity as an in vitro assay for heterozygote identification of ataxia-telangiectasia. Radiat Res 128: $90-99$

West CM, Elyan SA, Berry P, Cowan R, Scott D (1995) A comparison of the radiosensitivity of lymphocytes from normal donors, cancer patients, individuals with ataxia-telangiectasia $(\mathrm{A}-\mathrm{T})$ and $\mathrm{A}-\mathrm{T}$ heterozygotes. Int $\mathrm{J}$ Radiat Biol 68: 197-203 